\title{
Evaluasi Program Pelatihan In House Training (IHT) di Sekolah Dasar Swasta
}

\author{
Aih Ervanti Ayuningtyas \\ Magister Manajemen Pendidikan \\ Universitas Kristen Satya Wacana Salatiga \\ aih.ayuningtyas@gmail.com \\ Slameto \\ Magister Manajemen Pendidikan \\ Universitas Kristen Satya Wacana Salatiga \\ slameto@staff.uksw.edu \\ Yari Dwikurnaningsih \\ Magister Manajemen Pendidikan \\ Universitas Kristen Satya Wacana Salatiga \\ yari.dwikurnaningsih@staff.uksw.edu
}

\begin{abstract}
The purpose of this study is to evaluate the instructional, institutional, and behavioral dimensions of the In-House Training (IHT) program at the SD Muhammadiyah (Plus) Salatiga Academic Year 2013/2014. This is an evaluative study with Three Dimensional Cube Model. Data collection techniques used interviews, questionnaires, and document studies. Collected data then analyzed descriptively, ordinal data were analyzed using Three Box Method. Validation of data using technique and/or source triangulation. The results showed: (1) In the instructional dimension including organization, content/material, methodology, facilities, and cost included in good category, although there is little improvement in adjusting method with program objectives; (2) In the institutional dimension that includes speakers, trainees, administrator/committees, education specialists, families, and communities are included in either category, although there is still need for improvement in terms of needs analysis in terms of the needs of teachers; (3) In the behavioral dimension that is the goal of the IHT program and is divided into the cognitive, affective, and psychomotor domains almost all have been achieved well, although there is one goal in the psychomotor realm that has not been achieved well because one goal is not a priority to be achieved in time of three years. Recommendations for program sustainability, programs can be continued with improvements.
\end{abstract}

Keywords: IHT, program evaluation, Three Dimensional Cube

\section{Article Info}


Kelola: Jurnal Manajemen Pendidikan, Vol. 4, No. 2, Juli-Desember 2017

\section{PENDAHULUAN}

Guru yang bermutu merupakan salah satu kunci keberhasilan dari pendidikan yang bermutu. Guru dikatakan bermutu jika ia memiliki kompetensi yang baik. Oleh karena itu seiring dengan perkembangan zaman yang semakin maju maka guru harus senantiasa meningkatkan kompetensinya. Salah satu cara untuk meningkatkan kompetensi guru adalah dengan pendidikan dan pelatihan (diklat). Diklat dapat dilakukan melalui lembaga penyelenggara diklat maupun pihak sekolah sesuai dengan tujuan yang hendak dicapai. Guna meningkatkan kompetensi sesuai dengan visi, misi, tujuan, permasalahan maupun potensi yang dimiliki sekolah maka diklat dapat dilakukan secara mandiri oleh sekolah melalui In House Training (IHT).

Secara umum, Basri dan Rusdiana (2015: 227) mengemukakan bahwa In House Training adalah program pelatihan yang diselenggarakan di tempat peserta pelatihan atau di sekolah dengan mengoptimalkan potensi-potensi yang ada di sekolah, menggunakan peralatan kerja peserta pelatihan dengan materi yang relevan dan permasalahan yang sedang dihadapi, sehingga diharapkan peserta dapat lebih mudah menyerap dan mengaplikasikan materi untuk menyelesaikan dan mengatasi permasalahan yang dialami dan mampu secara langsung meningkatkan kualitas dan kinerjanya. Musfah (2011: 82) mengemukakan bahwa pelatihan pada dasarnya bertujuan untuk mengembangkan kompetensi guru. Kompetensi guru yang dimaksud antara lain pengetahuan, sikap, dan keterampilan. Hal senada diungkapkan Sherwood dan Best (Sudjoko, 2012: 40-45) bahwa pelatihan adalah proses membantu sumber daya dalam suatu organisasi agar mendapat efektivitas dalam pekerjaan mereka yang sekarang atau yang akan datang melalui pengembangan skill, knowledge, dan atittude. Berdasarkan pemaparan-pemaparan tersebut dapat disimpulkan bahwa IHT merupakan program yang diselenggarakan di sekolah atau tempat lain menggunakan peralatan dan materi yang relevan dengan permasalahan yang dihadapi, tujuannya adalah untuk mengembangkan kompetensi berupa skill, knowledge,dan atittude.

SD Muhammadiyah (Plus) Salatiga adalah salah satu sekolah yang menerapkan pelatihan In House Training secara mandiri dan terprogram. Dikatakan mandiri, karena sekolah ini mengadakan program pelatihan IHT atas prakarsa dan biaya sendiri, dan dikatakan terprogram karena program pelatihan IHT di sekolah ini dilaksanakan setiap tahun. Berdasarkan wawancara kepada Wakil Kepala SD Muhammadiyah (Plus) tanggal 23 September 2016, program pelatihan IHT telah dilaksanakan secara intensif sejak tujuh tahun lalu. IHT sendiri diselenggarakan untuk meningkatkan kompetensi guru dalam rangka mencapai visi sekolah sebagai "sekolah unggulan".

Berdasarkan hasil wawancara kepada Wakil Kepala SD Muhammadiyah (Plus) tanggal 23 September 2016, diketahui bahwa program pelatihan IHT SD Muhammadiyah (Plus) Salatiga utamanya diselenggarakan setahun sekali, yaitu setiap libur kenaikan kelas. Akan tetapi ada kalanya program pelatihan tersebut dilaksanakan lagi di waktu lain jika terdapat kompetensi guru yang penting dan mendesak untuk segera dikembangkan. Pada tahun pelajaran 2013/2014 SD Muhammadiyah (Plus) Salatiga menyelenggarakan IHT dengan tema "Melejitkan Prestasi Tiada Henti". Tujuan khusus dari kegiatan IHT tersebut adalah untuk meningkatkan kompetensi guru dari segi pengetahuan, sikap, dan keterampilan. Target pencapaian tujuan dari kegiatan IHT tersebut dapat diketahui tiga tahun sejak diselenggarakannya program pelatihan IHT, yaitu pada tahun 2016/2017. Oleh karena itu program IHT SD Muhammadiyah (Plus) Salatiga tahun pelajaran 2013/2014 tersebut perlu dilakukan evaluasi.

Pada beberapa kasus, pelatihan memang berhasil meningkatkan pengetahuan dan keterampilan guru. Akan tetapi pada beberapa penelitian diketahui bahwa adakalanya pelatihan gagal dalam meningkatkan kompetensi guru karena disebabkan oleh 
Evaluasi Program Pelatihan In House Training (IHT) Di Sekolah Dasar Swasta | Aih E. Ayuningtyas, dkk.

beberapa faktor. Berdasarkan hasil penelitian Eliyanto (2013: 34-47) faktor penyebab ketidak-efektifan pelatihan dalam meningkatkan profesionalisme guru adalah pemberian materi yang kurang tepat sehingga tidak terjadi peningkatan pengetahuan dan keterampilan, pelatihan kurang direncana-kan dengan matang, komponen pelatihan seperti penyajian teori, umpan balik, dan lainnya tidak dilakukan dengan baik, penggunaan metode pelatihan kurang tepat, dan motivasi dalam mengikuti pelatihan rendah. Berdasarkan hasil meta analisis yang dilakukan Sudana (2011: 133-156) terdapat beberapa faktor yang menyebabkan guru tidak produktif pasca pelatihan, yaitu: belum adanya manajemen yang dibakukan pasca pelatihan oleh sekolah, kurangnya dukungan fasilitas yang dimiliki sekolah, rendahnya kinerja guru, tidak sesuainya materi pelatihan yang diberikan dengan fasilitas yang dimiliki sekolah, dan kurangnya inisiatif guru yang bersangkutan dalam mengembangkan hasil pelatihan.

Berdasarkan uraian yang telah dipaparkan, penelitian ini dimaksudkan untuk mengevaluasi ketercapaian tujuan khusus pada program pelatihan IHT SD Muhammadiyah (Plus) Salatiga dan faktor keberhasilan atau pun kegagalannya. Evaluasi ini dibatasi dengan model evaluasi Three Dimensional Cube. Model evaluasi ini digunakan dengan pertimbangan bahwa Three Dimensional Cube tidak hanya bertujuan untuk mengetahui ketercapaian tujuan program tetapi juga menganalisis faktor keberhasilan atau kegagalan program. Hammond (1968: 1-9) berpen-dapat bahwa keberhasilan atau kegagalan suatu program ditentukan oleh interaksi komponen-komponen dalam pendidikan. Komponen-komponen tersebut selanjutnya dikelompokkan dalam struktur tiga dimensi. Interaksi antar variabel dari masingmasing dimensi menghasilkan kombinasi variabel dan digambarkan sebagai faktor yang perlu dipertimbangkan dalam evaluasi program.

Three Dimensional Cube merupakan model evaluasi yang terdiri dari dimensi instructional, dimensi institutional, dan dimensi behavior. Dimensi instructional terdiri dari lima variabel, yaitu variable organisasi, konten, metodologi, fasilitas, dan biaya. Dimensi institutional terdiri dari variabel siswa, guru, administrator, spesialis pendidikan, keluar-ga dan komunitas. Adapun dimensi behavior terdapat tiga variabel, yaitu kognitif, afektif dan psikomotor.

Rivai dan Murni (2012: 12) serta Basri dan Rusdiana (2015: 38-41) mengemukakan beberapa faktor yang perlu diperhatikan dalam pelaksanaan suatu program agar berhasil, diantaranya: tujuan, instruktur, materi, metode, peserta, pembagian waktu, lingkungan, dan media. Selain itu Hammond (1968:2-6) menambahkan beberapa faktor lain, yaitu pembagian waktu dalam satu materi, fasilitas, biaya, administrator atau panitia, spesialis pendidikan, keluarga dan komunitas.

Adapun kajian hasil penelitian terdahulu yang relevan dengan penelitian ini, antara lain: pertama adalah penelitian Putri (2013: 522527). Penelitiannya bertujuan untuk mengevaluasi program pelatihan Pendekatan Matematika Realistik Indonesia (PMRI) bagi guru matematika di Sumatera Selatan. Hasil temuan dari evaluasi dengan model Kirkpatrick ini menunjukkan bahwa seluruh peserta mempunyai reaksi positif terhadap program pelatihan karena materi yang diberikan relevan dengan kebutuhan dan tugas guru di sekolah, peserta mampu mengajarkan materi dengan baik saat dilakukan simulasi, serta seluruh peserta dapat memahami materi pelatihan dengan baik, sehingga dapat dilakukan pelatihan lanjutan.

Kedua adalah penelitian dari Riza (2014: 90-100) yang bertujuan untuk mengetahui efektivitas Program Pendidikan dan Latihan Berjenjang Tingkat Dasar Pendidik dan Tenaga Kependidikan (PTK) PAUD. Hasil evaluasi dengan model evaluasi Kirkpatrick ini diketahui bahwa penyelengaraan diklat termasuk dalam kategori baik walaupun masih perlu dilakukan perbaikan pada rekrutmen peserta yang tidak sesuai dengan kriteria yang ditetapkan, jadwal pelatihan terlalu padat, 
narasumber terlalu teoretis, tidak adanya evaluasi dan monitoring pasca evaluasi, ada beberapa materi yang kurang relevan dengan tugas guru di sekolah masing-masing, pasca pelatihan peserta belum sepenuhnya melakukan pembelajaran seperti yang diajarkan pada Diklat, serta dampak dari segi kualitas dan jumlah hasil karya guru belum sepenuhnya meningkat.

Ketiga adalah penelitian Pahlevi (2016) yang bertujuan untuk mengevaluasi konteks, input, proses, dan produk penyelenggaraan Program Diklat Kompe-tensi Plus di BPDIKJUR. Penelitian dengan model evaluasi CIPP (Context, Input, Process, Product) ini menunjukkan bahwa pelaksanaan Program Diklat diharapkan dapat meningkatkan kompetensi guru seiring dengan kemajuan teknologi; program diklat mampu menjembatani kesenjangan antara hasil pembelajaran dengan standar kerja yang dibutuhkan; program diklat memiliki stakeholder yang selalu mendukung pelaksanaan program, dan sangat membantu keberhasilan program; pelaksanaan program diklat berjalan dengan baik walupun terdapat beberapa kendala. Oleh karena itu, Program Diklat Kompetensi Plus di BPDIKJUR dapat terus dilakukan dengan perbaikan pada sistem perencanaan, pelaksanaan, dan evaluasi.

Keempat adalah penelitian yang dilakukan Uysal (2014: 17-26). Tujuan penelitiannya adalah untuk mengevaluasi keberhasilan program in-service education training (INSET) dalam mencapai tujuan khusus, serta kegunaan dan dampak program pada afektif guru, pengetahuan guru, serta praktek mengajar di kelas. Hasil evaluasi dengan model evaluasi Guskey ini menunjukkan bahwa secara umum para guru menunjukkan sikap positif terhadap program dan pelaksanaan program memiliki banyak segi positif. Akan tetapi pada tahap perencanaan dan evaluasi program masih terdapat masalah, antara lain: program belum memiliki komponen tindak lanjut (follow up), tidak mencukupinya materi dan sumber daya, seting pelatihan yang tidak nyaman, dan yang lebih serius adalah isi dari program pelatihan tidak berdasarkan kebutuhan kontekstual guru karena guru tidak dilibatkan dalam perencanaan dan pelaksanaan program.

Terakhir adalah penelitian dari Yussof, dkk (2016: 630-636). Penelitiannya bertujuan untuk menilai reaksi guru terhadap in-service teacher training program pada School Based Assessment. Hasil evaluasi dengan model Kirkpatrick ini menunjukkan bahwa SBA inservice teacher training program telah mencapai tujuan. Tingkat kepuasan peserta atas reaksi terhadap fasilitas fisik memuaskan, reaksi terhadap materi pembelajaran memuaskan, reaksi terhadap materi pengajaran memuaskan, reaksi terhadap penyampaian materi oleh fasilitator memuaskan, reaksi terhadap konten umum pelatihan memuaskan. Berdasarkan hasil analisis kuantitatif diketahui bahwa aspek konten umum, fasilitas fisik dan materi pembelajaran memiliki korelasi signifikan dan kontribusi terhadap perubahan pengetahuan dan keterampilan guru, dan aspek konten umum, materi konstruksional dan materi pembelajaran memiliki korelasi signifikan terhadap perubahan sikap guru. Oleh karena itu program dapat dilanjutkan dengan beberapa peningkatan.

Beberapa hal yang membedakan antara penelitian ini dengan lima penelitian sebelumnya antara lain penelitian ini menggunakan model evaluasi Three Dimensional Cube sehingga tahapan penelitian serta aspek yang diteliti terdapat perbedaan. Perbedaan tersebut terletak pada aspek organisasi, spesialis pendidikan, keluarga, komunitas, dan tujuan program yang disesuaikan dengan visi misi sekolah dan yayasan yang menaungi sekolah.

\section{METODE PENELITIAN}

Penelitian ini merupakan penelitian evaluatif menggunakan model evaluasi Three Dimensional Cube. Penelitian dilakukan di SD Muhammadiyah (Plus) Salatiga mengenai evaluasi Program In House Training (IHT) tahun pelajaran 2013/2014. Sumber informasi dalam penelitian ini adalah Wakil Kepala 
Evaluasi Program Pelatihan In House Training (IHT) Di Sekolah Dasar Swasta | Aih E. Ayuningtyas, dkk.

Sekolah, panitia penyelenggara IHT, dan guru sebagai peserta IHT. Teknik pengumpulan data yang digunakan adalah dengan wawancara, angket, dan studi dokumen. Adapun dokumen yang digunakan adalah "Panduan In House Training SD Muhammadiyah (Plus) Kota Salatiga Tahun Ajaran 2013/2014".

Angket menggunakan rating scale dari skala 1 sampai 5, untuk mengetahui tingkat kepuasan peserta terhadap IHT. Uji validitas korelasi Product Moment dengan nilai $\mathrm{r}_{\text {tabel }}$ pada taraf signifikansi $5 \%$ dan $\mathrm{N}=13$ adalah 0,553 menunjukkan bahwa pada try out 1 terdapat dua item yang tidak valid, sehingga perlu direvisi dan diujikan kembali. Pada try out 2 seluruh item dinyatakan valid. Pada uji reliabilitas didapat nilai Cronbach's Alpha sebesar 0,755 sehingga lebih dari 0,6.

Data kualitatif maupun kuantitatif yang telah terkumpul selanjutnya dianalisis secara deskriptif. Data angket yang bersifat ordinal dianalisis menggunakan three box method yaitu data angket ditabulasi untuk dihitung nilai indeksnya, kemudian dikelompokkan ke dalam kategori rendah, sedang, atau tinggi. Berikut merupakan rentang untuk masing-masing kategori:

Tabel 1

Rentang Kategori Angka Indeks

\begin{tabular}{ccc}
\hline NO & RENTANG & KATEGORI \\
\hline 1 & $3,2-7,4$ & rendah \\
2 & $7,5-11,7$ & sedang \\
3 & $11,8-16,0$ & tinggi \\
\hline
\end{tabular}

Sumber: data angket yang ditabulasi

\section{HASIL PENELITIAN DAN \\ PEMBAHASAN}

\section{Hasil Penelitian}

Dimensi Instructional

Dimensi instructional terdiri dari variabel organisasi, konten, metodologi, fasilitas, dan biaya. Organisasi meliputi kesesuaian materi pelatihan terhadap level peserta, pengurutan materi dari mudah ke sulit, dan durasi waktu dalam satu materi. Materi atau konten berisi topik-topik yang diberikan dalam pelatihan, dan kesesuaian topik dengan tujuan pelatihan. Metodologi meliputi aktivitas mengajar (pemilihan dan kesesuaian metode penyampaian materi), tipe interaksi, dan prinsip-prinsip pembelajaran atau teori belajar yang digunakan dalam pelatihan. Fasilitas meliputi pelayanan dan fasilitas yang diperlukan dalam pelatihan (ruang pelatihan, media dll). Biaya meliputi penggunaan biaya untuk pelatihan.

Tabel 2

Hasil Tabulasi Angket Dimensi Instructional

\begin{tabular}{clcc}
\hline NO & INDIKATOR & INDEKS & KATEGORI \\
\hline 1 & Organisasi & 14.6 & Tinggi \\
2 & Konten & 15.6 & Tinggi \\
3 & Metodologi & 14 & Tinggi \\
4 & Fasilitas & 15.3 & Tinggi \\
& Rata-rata & $\mathbf{1 4 . 7}$ & Tinggi \\
\hline
\end{tabular}

Sumber: data penelitian yang diolah dan dikelompokkan sesuai kategori

Berdasarkan tabel 2 diketahui bahwa rata-rata nilai indeks untuk dimensi instructional sebesar 14.7, artinya persepsi peserta terhadap variabel organisasi, konten, metodologi dan fasilitas termasuk dalam kategori tinggi. 
Kelola: Jurnal Manajemen Pendidikan, Vol. 4, No. 2, Juli-Desember 2017

Selain itu, berdasarkan data angket, wawancara dan dokumentasi pada kategori organisasi diketahui bahwa informasi dari materi yang disampaikan sesuai dengan profesi peserta, materi yang disampaikan dalam IHT sesuai dengan level peserta atau tidak melenceng dari profesi peserta sebagai guru di SD Muhammadiyah (Plus) Salatiga, materi diurutkan dari materi mudah ke materi sulit, durasi IHT yang diselenggarakan selama dua hari sudah baik. Pada kategori konten diketahui bahwa topik-topik yang diberikan dalam pelatihan didasarkan pada kebutuhan guru yang disesuaikan dengan visi, misi sekolah, topik yang diberikan sesuai dengan tujuan IHT karena tujuan IHT dirumuskan bersama antara guru dan pimpinan sekolah. Pada kategori metode diketahui bahwa metode penyampaian materi dalam IHT sesuai dengan materi yang diberikan, fasilitas yang sering dimanfaatkan dalam penyampaian materi adalah IT (Teknologi Informasi), interaksi antara pemateri dan peserta dilakukan dengan baik, dan penggunaan teori belajar sudah sangat baik. Pada kategori fasilitas diketahui bahwa IHT diselenggarakan di hotel karena lebih terjamin kenyamanan yang ditawarkannya, mulai dari makanan, penginapan, ruang presentasi hingga media untuk presentasi. Pada kategori biaya diketahui bahwa seluruh biaya yang diperlukan untuk IHT berasal dari anggaran sekolah, dan jika anggaran sekolah tidak mencukupi maka panitia mencari donatur dari luar sekolah untuk menutupi kekurangan tersebut.

Dimensi Institutional

Dimensi institutional terdiri dari variabel siswa, guru, administrator, spesialis pendidikan, keluarga dan komunitas. Siswa atau peserta IHT berisi identifikasi usia, jenis kelamin, prestasi, serta minat atau motivasi. Guru atau pemateri berisi identifikasi latar belakang pendidikan, dan pengalaman kerja. Panitia mengenai pemilihan dan kualifikasinya. Spesialis pendidikan mengenai keterlibatannya dalam pelatihan. Keluarga dan komunitas perlu mengenai bentuk dukungannya terhadap keberhasilan program pelatihan.

Tabel 3 Hasil Tabulasi Angket Dimensi Institutional

\begin{tabular}{clcc}
\hline NO & \multicolumn{1}{c}{ INDIKATOR } & INDEKS & KATEGORI \\
\hline 1 & Pemateri & 15.2 & Tinggi \\
2 & Dukungan Keluarga & 15.6 & Tinggi \\
3 & Dukungan Komunitas & 16 & Tinggi \\
& Rata-rata & $\mathbf{1 5 . 4}$ & Tinggi \\
\hline
\end{tabular}

Sumber: data penelitian yang diolah dan dikelompokkan sesuai kategori

Berdasarkan tabel 3 diketahui bahwa pada dimensi institutional diperoleh nilai indeks sebesar 15.5. Hal ini berarti persepsi peserta terhadap pemateri, dukungan keluarga dan dukungan komunitas termasuk dalam kategori tinggi.

Selain itu, berdasarkan data angket, wawancara dan dokumentasi pada kategori pemateri diketahui bahwa pemateri menguasai materi dengan baik, jelas, dan tepat sasaran karena pemateri merupakan para ahli di bidangnya. Selain itu pemateri memberikan kesempatan kepada peserta untuk menanyakan materi yang kurang jelas. Walaupun secara umum pemateri mendapat penilaian yang baik dari para peserta, namun peserta mengharapkan agar pada IHT yang diselenggarakan tahun depan dihadirkan seorang motivator agar lebih 176 termotivasi lagi untuk mengajar. Pada kategori peserta diketahui bahwa seluruh peserta pelatihan merupakan seluruh guru SD Muhammadiyah (Plus) Salatiga yang mengajar dari kelas satu sampai enam. Berdasarkan angket terbuka, diketahui motivasi peserta untuk mengikuti IHT adalah program IHT merupakan program wajib yang harus diikuti oleh seluruh guru, karena program IHT dapat menambah wawasan yang dapat menunjang profesinya, menyatukan visi misi, meningkatkan komitmen guru sebagai bagian dari SD Muhammadiyah (Plus) Salatiga, meningkatkan semangat dan etos kerja, mempererat tali persaudaraan antar teman sekerja, dan dapat menyusun program-program berkualitas yang akan berdampak pada kemajuan sekolah. Pada kategori spesialis 
Evaluasi Program Pelatihan In House Training (IHT) Di Sekolah Dasar Swasta | Aih E. Ayuningtyas, dkk.

pendidikan diketahui bahwa spesialis pendidikan memberikan dukungan kepada sekolah-sekolah yang hendak mengembangkan kompetensi guru melalui pelatihan yang diadakan secara mandiri. SD Muhammadiyah (Plus) Salatiga pun melibatkan spesialis pendidikan sebagai salah satu pemateri dalam IHT. Pada kategori keluarga diketahui bahwa keluarga mendukung para peserta untuk mengikuti IHT karena keluarga menyadari bahwa kegiatan IHT merupakan kegiatan yang wajib untuk diikuti peserta sebagai bagian dari profesionalisme kerja di SD Muhammadiyah (Plus) Salatiga. Pada kategori komunitas diketahui bahwa komunitas turut memberi dukungan dan menjadi perantara pimpinan sekolah untuk mengawasi perubahan perilaku guru setelah mengikuti IHT.

\section{Dimensi behavior}

Terdapat tiga variabel dalam dimensi behavior, yaitu kognitif, afektif dan psikomotor. Pada penelitian ini ketiga variabel dijabarkan sebagai berikut: a) variabel kognitif dibatasi dalam dua tingkatan, yaitu menambah pengetahuan dan wawasan dan mengaplikasikan pengetahuan dari materi yang disampaikan dalam IHT; b) variabel afektif yang meliputi sikap guru dalam mendukung visi sekolah, peningkatan minat mengajar, peningkatan ketertiban dalam melaksanakan ibadah, dan penyesuaian diri dalam organisasi; dan c) variabel psikomotor meliputi kemampuan memberi penilaian hasil belajar siswa sesuai K-13, kemampuan melakukan diversifikasi model dan metode pembelajaran, kemampuan membuat inovasi teknologi dalam pembelajaran, penggunaan bahan ajar yang bervariasi, merencanakan pengembangan karir akademik berbasis prestasi, penggunaan Bahasa Arab dan Bahasa Inggris, meningkatkan praktek religiusitas, serta peningkatan prestasi guru.

Tabel 4

Hasil Tabulasi Angket Dimensi behavior

\begin{tabular}{clcc}
\hline NO & INDIKATOR & INDEKS & KATEGORI \\
\hline 1 & Kognitif & 14 & Tinggi \\
2 & Afektif & 15.3 & Tinggi \\
3 & Psikomotor & 13.2 & Tinggi \\
& Rata-rata & $\mathbf{1 4}$ & Tinggi \\
\hline
\end{tabular}

Sumber: data penelitian yang diolah dan dikelompokkan sesuai kategori

Berdasarkan tabel empat diketahui bahwa rata-rata indeks dimensi behavior sebesar 14 . Hal ini berarti bahwa pencapaian tujuan khusus pada aspek kognitif, afektif, dan psikomotor peserta pelatihan termasuk dalam kategori tinggi.

Berdasarkan angket dan wawancara diketahui bahwa pada aspek kognitif nilai indeks tertinggi terdapat dalam indikator kontribusi pelatihan IHT dalam menambah pengetahuan Kemuhammadiyahan karena materi banyak yang membahas dan berdasar pada kemuhammadiyahan. Adapun nilai indeks terendah ada pada indikator kontribusi IHT dalam menambah pengetahuan tentang penilaian hasil belajar Kurikulum 2013. Bahkan ada beberapa guru yang menilai bahwa IHT kurang atau tidak memiliki kontribusi dalam menambah pengetahuan tentang penilaian hasil belajar Kurikulum 2013. Alasannya adalah karena guru tersebut tidak mendapat kesempatan untuk mempraktekan penilaian hasil belajar Kurikulum 2013 tersebut secara langsung. Keterangan tersebut nampaknya sesuai dengan dokumen Panduan Kegiatan IHT yang tertulis bahwa metode yang digunakan hanya ceramah, tanya jawab, dan diskusi tanpa ada praktek atau simulasi. Pada aspek afektif nilai indeks tertinggi terdapat pada indikator dukungan guru terhadap misi sekolah dam minat mengajar guru. Guru banyak yang beralasan bahwa keikutsertaannya dalam kegiatan IHT selain untuk melaksanakan kewajiban tetapi juga ingin menyatukan misi dan untuk meningkatkan minat mengajar di SD Muhammadiyah (Plus) Salatiga. Adapun nilai 
indeks terendah terdapat pada indikator ketertiban guru dalam melaksanakan ritual ibadah. Walaupun memiliki indeks terendah, tetapi indikator tersebut masih termasuk dalam kategori tinggi. Hal ini menunjukkan bahwa IHT telah berhasil mencapai tujuan khusus program dari segi afektif peserta IHT. Pada aspek psikomotor walaupun rata-rata nilai indeks termasuk kategori tinggi tetapi ada satu indikator yang masih termasuk kategori cukup, yaitu pada kategori kemampuan menggunakan Bahasa Arab dan Bahasa Inggris. Hal ini nampaknya terjadi karena kemampuan menggunakan Bahasa Arab dan Bahasa Inggris bukan menjadi prioritas dalam tujuan khusus program. Sedangkan nilai indeks tertinggi terdapat pada indikator kemampuan guru dalam melakukan diversifikasi model dan metode pembelajaran setelah mengikuti pelatihan IHT.

\section{Pembahasan}

\section{Dimensi Instructional}

Pada sub variabel organisasi diketahui bahwa materi yang diberikan sesuai dengan level peserta yang dalam penelitian ini adalah guru SD Muhammadiyah (Plus) Salatiga. Hasil temuan ini berbeda dengan temuan dalam penelitian yang dilakukan oleh Pahlevi (2016) bahwa pengelompokan materi pelatihan yang belum tersusun berdasarkan level membuat peta kompetensi pendidik sulit terlacak yang akhirnya dapat menghambat keberhasilan program. Selain itu, pembagian durasi waktu masing-masing materi dalam jadwal diklat juga perlu dipertimbangkan. Berdasarkan temuan dalam penelitian ini, pembagian waktu dalam IHT SD Muhammadiyah (Plus) Salatiga mendapat penilaian baik dari para peserta. Hal ini dikarenakan materi yang diberikan tidak terlalu banyak dan waktu yang dialokasikan cukup untuk penyampaian materi dan tanya jawab. Lain halnya dengan hasil temuan dalam penelitian Riza (2014: 90-100) bahwa jadwal diklat terlalu padat sehingga menyulitkan peserta dalam membagi waktu untuk berbagai aktivitas dalam diklat. Pengaturan jadwal yang tidak efektif tersebut dikarenakan terlalu banyak materi yang diberikan.
Pada sub variabel konten Pahlevi (2016) mengemukakan bahwa diperlukan analisis kebutuhan yang disesuaikan dengan tujuan penyelenggara untuk menentukan topik pelatihan agar dapat meningkatkan kompetensi pesertanya. Hal ini senada hasil temuan dalam penelitian ini bahwa topik IHT dipilih berdasarkan kebutuhan guru di SD Muhammadiyah (Plus) Salatiga yang disesuaikan dengan visi, misi, dan tujuan sekolah. Topik sendiri dipilih dengan cara musyawarah antar warga sekolah, terutama guru dan para pimpinan sekolah. Pada variabel materi, seluruh materi dalam IHT SD Muhammadiyah (Plus) Salatiga penting untuk menunjang kompetensinya. Hasil ini berbeda dengan hasil penelitian Riza (2014: 90-100) dan Uysal (2014: 17-26) bahwa tidak semua materi dalam diklat dapat menunjang pekerjaan peserta, dan terdapat materi yang tidak sesuai dengan kebutuhan guru sehingga tujuan program tidak dapat tercapai dengan baik.

Pada sub variabel metodologi, Pahlevi (2016) mengemukakan metode pelatihan yang digunakan dalam diklat adalah metode ceramah, dan praktek langsung karena materi diklat lebih menitikberatkan pada bidang kejuruan. Uysal (2014: 17-26) mengemukakan bahwa sehubungan dengan topik pelatihan mengenai keterampilan mengajar bahasa maka panitia menggunakan metode simulasi agar peserta dapat mempraktekkan secara secara langsung tugas yang diberikan pelatih, tetapi kelas tidak disetting dengan baik sehingga kelas terlalu sesak. Lain halnya dalam penelitian ini, IHT menggunakan metode ceramah, tanya jawab, dan diskusi ini dipilih karena sesuai dengan materi yang hendak disampaikan dalam IHT yang lebih banyak pada teori dan penyusunan strategi. Selain itu, terdapat variabel lain yang tidak dikemukakan dalam penelitian sebelumnya, yaitu prinsip-prinsip belajar untuk menguatkan sikap yang menggambarkan pencapaian tujuan, membangun motivasi agar tujuan pelatihan dapat dicapai secara efektif, mengaplikasikan prinsip pemecahan masalah, merencanakan pembelajaran agar sesuai dengan kecakapan 
Evaluasi Program Pelatihan In House Training (IHT) Di Sekolah Dasar Swasta | Aih E. Ayuningtyas, dkk.

peserta, membuat peserta mampu melakukan hal-hal yang diajarkan dalam pelatihan, dan peserta ikut berpartisipasi dalam pelatihan tersebut.

Pada sub variabel fasilitas, Putri (2013: 522-527) mengemukakan bahwa yang termasuk dalam fasilitas adalah fasilitas akomodasi, konsumsi, dan tentang pelayanan dari panitia penyelenggara. Lain halnya dengan Riza (2014: 90-100) yang mengemukakan bahwa fasilitas yang diberikan dalam pelatihan yang ditelitinya antara lain akomodasi, konsumsi, dan fasilitas ruangan, tetapi tidak disediakannya ruang khusus untuk ibadah dapat menghambat efektivitas pelaksanaan pelatihan. Temuan lain dari Pahlevi (2016) dijelaskan bahwa fasilitas yang diberikan oleh penyelenggara mulai dari penginapan, sarana peralatan untuk praktek dan ruang untuk menyampaikan materi, akan tetapi fasilitas penginapan yang diberikan tidak sama antara peserta satu dengan peserta lain sehingga mempengaruhi kepuasan dan kenyamanan peserta. Selain itu sarana peralatan untuk praktek yang terkini yang sesuai dengan kebutuhan industri juga masih kurang, sehingga dapat menghambat ketercapaian tujuan program. Lain halnya pada temuan Uysal (2014: 17-26) bahwa dari berbagai fasilitas yang diberikan, terdapat satu fasilitas yang kurang baik, yaitu ketersediaan materi yang tidak mencukupi untuk seluruh peserta dan tidak ada materi baru yang dikembangkan pihak penyelenggara. Temuan-temuan yang telah dikemukakan berbeda dengan hasil temuan dalam penelitian di SD Muhammadiyah (Plus) Salatiga. Fasilitas yang diberikan dalam IHT merupakan fasilitas yang disediakan oleh tempat atau hotel dimana IHT diselenggarakan, yaitu berupa penginapan, makanan, tempat untuk pertemuan, dan kualitas media. Peserta menilai pelayanan dan fasilitas pelatihan IHT sudah memuaskan.

Pada sub variabel biaya, Pahlevi (2016) dalam penelitiannya mengemukakan bahwa biaya yang diperlukan untuk diklat berasal dari dana APBD sehingga besarnya anggaran menjadi masalah tersendiri bagi penyelenggaraan program diklat karena akan berpengaruh terhadap jumlah peserta dan durasi waktu diklat. Dalam penelitiannya dikatakan bahwa panitia akan menyesuaikan jumlah peserta dengan dana yang ada. Temuan tersebut berbeda dengan temuan dalam penelitian ini karena biaya yang diperlukan untuk IHT berasal dari sekolah. Walapun biaya memang berpengaruh terhadap jumlah peserta, fasilitas yang akan diberikan kepada peserta dan durasi waktu untuk IHT, akan tetapi panitia IHT di SD Muhammadiyah (Plus) Salatiga selalu berusaha untuk mencukupi biaya yang diperlukan agar IHT dapat berjalan dengan baik sesuai dengan rencana dan tujuan. Apabila sumber dana yang dialokasikan sekolah kurang, maka panitia akan mencari sponsor untuk menutupi kekurangan tersebut daripada harus mengurangi peserta atau mengubah rencana dan tujuan IHT. Usaha yang dilakukan panitia ini merupakan cara yang baik karena kualitas IHT yang diselenggarakan dapat terjaga.

\section{Dimensi Institutional}

Pada sub variabel pemateri, Riza (2014: 90-100) mengemukakan bahwa pemateri atau narasumber tidak menguasai metode dengan baik karena pemateri terlalu teoritis dan tidak memberikan contoh konkrit pada materinya sehingga peserta sulit memahami materi yang disampaikan. Adapun temuan yang diperoleh dalam penelitian ini para peserta menilai bahwa para pemateri merupakan orang kompeten yang dapat menyampaikan materi sesuai dengan kebutuhan guru dan pemateri dapat memberikan materi secara jelas. Walaupun begitu para guru mengharapakan agar pada IHT berikutnya panitia mengundang motivator agar para guru lebih termotivasi dalam mengajar.

Pada sub variabel peserta pelatihan, Riza (2014: 90-100) mengemukakan bahwa rekrutmen peserta dalam penelitian termasuk dalam kategori baik namun dalam pelaksanaannya belum sesuai dengan kriteria umum dan khusus, yang diantaranya usia melebihi batas maksimal dan kualifikasi akademik tidak sesuai dengan syarat yang telah ditentukan. Adapun Pahlevi (2016) menjelaskan bahwa peserta diklat dipilih oleh 
panitia dan diambil dari sekolah yang memiliki paket keahlian sesuai dengan topik pelatihan dan memiliki peralatan yang menunjang di sekolah. Lain halnya dalam penelitian ini, peserta tidak diseleksi atau direkrut berdasarkan syarat-syarat tertentu karena pelatihan atau IHT hanya dilakukan dalam lingkup sekolah sehingga peserta IHT merupakan seluruh guru SD Muhammadiyah (Plus) Salatiga.

Pada sub variabel panitia, Putri (2013: 522-527) menjelaskan bahwa pelatihan diselenggarakan oleh lembaga diklat yang professional, sehingga mendapat tanggapan yang positif dari peserta. Selain itu, Pahlevi (2016) juga mengemukakan bahwa diklat diselenggarakan oleh lembaga diklat yang khusus menangani pendidikan kejuruan, akan tetapi lemahnya motivasi sebagian pegawai dalam melaksanakan tugas dapat menghambat keberhasilan program. Temuan-temuan yang telah dipaparkan agaknya tidak sama dengan temuan dalam penelitian ini karena penyelenggara IHT merupakan warga sekolah dan bukan lembaga yang secara khusus menangani program pelatihan. Penyelenggara merupakan panitia yang terdiri dari guru-guru SD Muhammadiyah (Plus) Salatiga. Walaupun begitu, panitia IHT memiliki semangat dan komitmen yang tinggi untuk mencapai keberhasilan program. Hal ini dibuktikan pada usaha panitia yang menggalang dana jika anggaran yang diberikan oleh sekolah kurang. Panitia IHT selalu berusaha untuk memberikan kualitas yang baik dalam pelaksanaan IHT.

Pada sub variabel spesialis pendidikan, penelitian yang dilakukan oleh Putri (2013: 522-527), Riza (2014: 90-100), Pahlevi (2016), Uysal (2014: 17-26) dan Yussof, dkk (2016: 630-636) selurunya mengemukakan bahwa pelatihan merupakan inisiatif dari dinas pendidikan atau menteri pendidikan (spesialis pendidikan) setempat sehingga seluruh biaya ditanggung oleh pemerintah. Lain halnya dengan pelatihan dalam penelitian ini, IHT di SD Muhammadiyah (Plus) Salatiga merupakan inisiatif dari sekolah, sehingga biaya yang dibutuhkan pun berasal dari sekolah. Peran spesialis pendidikan dalam IHT ini adalah memberikan izin terkait penyelenggaraan program IHT di SD Muhammadiyah (Plus) Salatiga. Selain itu, sehubungan dengan pegawai dinas pendidikan yang merupakan para ahli di bidang pendidikan, maka panitia IHT mengundang salah seorang pegawai dinas pendidikan untuk memberikan materi yang terkait dengan Kurikulum 2013.

Keluarga dan komunitas menjadi faktor yang juga turut andil dalam mencapai keberhasilan program pelatihan. Pada penelitian-penelitian terdahulu keluarga dan komunitas tidak dijelaskan sebagai faktor yang mempengaruhi keberhasilan program. Pada penelitian ini keluarga turut berperan dalam mempengaruhi motivasi peserta untuk mengikuti kegiatan IHT. Keluarga yang memberikan dukungan kepada peserta untuk mengikuti IHT akan menambah motivasi peserta, begitu pun sebaliknya. Selain itu komunitas guru turut mendukung dalam mencapai tujuan program karena komunitas dapat digunakan sebagai sarana untuk memantau perubahan perilaku yang ditunjukkan guru sebagai dampak dari pelatihan. Komunitas juga dapat digunakan sebagai sarana untuk sharing terhadap masalahmasalah yang dihadapi guru pada saat mengimplementasikan materi pelatihan.

\section{Dimensi Behavior}

Tujuan kognitif dari penelitian yang dilakukan oleh Putri (2013: 522-527) adalah meningkatkan kemampuan peserta mengenai Pendidikan Matematika Realistik Indonesia (PMRI) yang diukur dengan tes, dan mengaplikasikan materi melalui simulasi yang diukur melalui observasi. Adapun Riza (2014: 90-100) mengemukakan bahwa tujuan kognitif dari pelatihan dalam penelitiannya adalah meningkatkan pengetahuan akademik yang diukur dengan menggunakan tes. Hal senada juga ditunjukkan oleh Yussof, dkk (2016: 630636) bahwa tujuan kognitif dalam penelitiannya adalah meningkatkan pengetahuan peserta yang diukur melalui tes. Tes dalam penelitianpenelitian tersebut berfungsi untuk mengetahui perubahan pengetahuan peserta secara 
langsung setelah mengikuti pelatihan. Dalam penelitian ini tujuan kognitif dari penelitian adalah untuk meningkatkan pengetahuan dan mengaplikasikan materi IHT. Akan tetapi sehubungan dengan pelaksnaan IHT yang dilakukan tiga tahun yang lalu, dan baru dapat dilihat setelah tiga tahun sejak pelatihan dilakukan maka kurang efektif jika diukur menggunakan tes. Selain itu, tidak digunakannya tes dalam penelitian karena adanya keterbatasan waktu dan perizinan untuk memberikan tes kepada guru yang sebagian besar merupakan guru baru yang tidak mengikuti IHT tahun 2013/2014 ini. Berdasarkan temuan dalam penelitian ini, seluruh tujuan kognitif IHT telah tercapai dengan baik. Akan tetapi masih ada kekurangan yang perlu diperbaiki untuk kelanjutan program, yaitu mengenai kesesuaian metode dengan materi yang diberikan. Pada temuan ini ada beberapa guru yang menilai bahwa IHT kurang memiliki kontribusi dalam menambah pengetahuan tentang penilaian hasil belajar Kurikulum 2013 karena guru tersebut tidak mendapat kesempatan untuk mempraktekan penilaian hasil belajar Kurikulum 2013 tersebut secara langsung. Temuan ini menunjukkan bahwa metode yang digunakan masih perlu dikaji ulang agar lebih sesuai sehingga dapat mencapai tujuan dengan lebih baik lagi.

Tujuan afektif dalam pelatihan merujuk pada perubahan sikap peserta setelah mengikuti pelatihan. Riza (2014: 90-100) mengemukakan bahwa peserta yang mengikuti pelatihan tidak menunjukkan perubahan sikap sesuai dengan materi yang diajarkan dalam pelatihan. Penyebabnya adalah tidak adanya monitoring dari lembaga diklat setelah pelatihan selesai. Hasil temuan tersebut berbeda dengan hasil temuan pada penelitian ini karena tujuan afektif IHT yang meliputi kontribusi IHT dalam menambah dukungan misi sekolah, meningkatkan minat mengajar guru, meningkatkan ketertiban guru dalam melaksanakan ritual ibadah, dan kemampuan guru untuk menyesuaikan diri dalam organisasi sekolah seluruhnya dapat tercapai dengan baik. Ketercapaian itu merupakan hasil dari pengawasan yang dilakukan oleh pemimpin sekolah melalui komunitas-komunitas yang ada di sekolah.

Psikomotor merupakan tujuan pelatihan yang berkaitan dengan peningkatan keterampilan peserta setelah mengikuti pelatihan. Penelitian yang dilakukan oleh Riza (2014: 90-100) menghasilkan temuan bahwa tidak sepenuhnya tujuan psikomotor dapat dicapai, karena guru mempunyai prioritas sendiri tentang keterampilan yang penting untuk digunakan di tempat kerjanya. Oleh karena itu, materi yang tidak diprioritaskan tersebut kurang berhasil dalam meningkatkan keterampilan peserta. Temuan tersebut juga ditemukan dalam penelitian ini. Tujuan psikomotor dalam penelitian ini dibatasi pada kemampuan memberi penilaian hasil belajar siswa sesuai K13, kemampuan melakukan diversifikasi model dan metode pembelajaran, kemampuan melakukan inovasi teknologi dalam pembelajaran, penggunaan bahan ajar yang bervariasi, merencanakan pengembangan karir akademik berbasis prestasi, penggunaan Bahasa Arab dan Bahasa Inggris, meningkatkan praktek religiusitas, peningkatan prestasi guru. Hasilnya hampir semua tujuan psikomotor dapat tercapai dengan baik, tetapi ada satu tujuan yang masih belum tercapai, yaitu pada kategori kemampuan menggunakan Bahasa Arab dan Bahasa Inggris. Hal ini terjadi karena kategori tersebut bukan menjadi prioritas untuk segera dicapai dalam waktu tiga tahun. Tujuan psikomotor program lebih diprioritaskan pada pencapain prestasi sekolah. Akan tetapi prestasi yang diprioritaskan adalah peningkatan prestasi siswa. Oleh karena itu seharusnya peningkatan prestasi tidak hanya difokuskan untuk siswa saja, tetapi juga prestasi sekolah pada umumnya. Sekolah perlu memberikan dukungan untuk peningkatan prestasi guru. Walaupun beberapa guru sudah mewakili sekolah di tingkat kota, provinsi, bahkan nasional namun masih ada guru yang mempunyai minat tinggi untuk turut serta dalam meningkatkan prestasi tetapi kurang mendapat perhatian oleh pihak sekolah. 
Kelola: Jurnal Manajemen Pendidikan, Vol. 4, No. 2, Juli-Desember 2017

Pada akhirnya, penelitian ini mendukung temuan Astuti, S., Slameto, S., \& Dwikurnaningsih, Y. (2017) yang menyatakan bahwa pelatihan model In House Training dapat meningkatkan kemampuan guru SD Laboratorium Kristen Satya Wacana dalam menyusun instrumen penilaian ranah sikap; Temuan ini didasarkan data peningkatan persentase peserta pelatihan yang mencapai KKM (kriteria keberhasilan $\geq 60$ ) dari 76, 92\% pada siklus I menjadi $80 \%$ pada siklus II. Simpulan ini juga didukung capaian aktivitas trainer maupun peserta pelatihan pada kategori baik dan sangat baik untuk semua siklus.

\section{SIMPULAN DAN SARAN} Simpulan

Pada dimensi Instructional terdapat lima sub variabel, yaitu organisasi, konten/materi, metodologi, fasilitas, dan biaya. Rata-rata nilai indeks pada dimensi ini termasuk dalam kategori tinggi. Masing-masing sub variabel dalam dimensi Instructional ini pun termasuk dalam kategori tinggi.

Dimensi Institutional pada penelitian ini membahas tentang personil-personil yang berperan dalam IHT. Adapun sub variabel pada dimensi ini adalah pemateri, peserta, administrator atau panitia, spesialis pendidikan, keluarga, dan komunitas. Nilai indeks dari masing-masing sub variabel pada dimensi ini termasuk dalam kategori tinggi. Bahkan komunitas memiliki peran yang penting dalam mencapai tujuan program karena melalui komunitas, pemimpin sekolah dapat mengawasi perubahan perilaku guru setelah mengikuti pelatihan dalam rangka mencapai tujuan program IHT. Walaupun begitu para guru mengharapakan agar pada IHT berikutnya panitia mengundang motivator agar para guru lebih termotivasi dalam mengajar.

Dimensi behavior dalam penelitian ini menyangkut tujuan khusus dari program IHT yang di selenggarakan oleh SD Muhammadiyah (Plus) Salatiga. Adapun tujuan khusus yang dimaksud adalah peningkatan kompetensi guru yang terbagi dalam pengetahuan (kognitif), sikap (afektif), dan keterampilan (psikomotor). Seluruh tujuan kognitif tersebut dapat tercapai dengan baik, walaupun perlu ada perbaikan pada metode penyampaian materi agar dapat menambah pengetahuan lebih optimal lagi. Adapun tujuan afektif seluruhnya dapat tercapai dengan baik. Pada tujuan psikomotor hampir seluruhnya termasuk kategori baik. Akan tetapi masih ada satu tujuan psikomotor yang belum tercapai dengan baik, yaitu kemampuan menggunakan Bahasa Arab dan Bahasa Inggris. Hal ini terjadi karena kategori tersebut bukan menjadi prioritas untuk segera dicapai dalam waktu tiga tahun.

Berdasarkan penlitian dengan menggunakan model evaluasi Three Dimensional Cube Hammond untuk menganalisis Program Pelatihan In House Training (IHT) di SD Muhammadiyah (Plus) Salatiga, dapat disimpulkan bahwa program IHT yang dilaksanakan pada tahun ajaran 2013/2014 telah mencapai tujuan walaupun masih perlu perbaikan.

\section{Saran}

Berdasarkan simpulan yang telah dipaparkan, maka dapat disarankan agar sekolah hendaknya membuat perencanaan yang lebih matang dengan mempertimbangkan metode penyampaian materi yang sesuai dengan tujuan materi; sekolah hendaknya melakukan analisis kebutuhan bukan hanya untuk menentukan topik tetapi juga untuk menentukan pemateri yang dibutuhkan peserta; sekolah hendaknya tidak memprioritaskan beberapa tujuan saja, agar seluruh tujuan dapat dicapai secara optimal dan menetapkan kegiatan untuk mencapai tujuan tersebut, misalnya untuk meningkatkan kemampuan Bahasa Arab dan Bahasa Inggris perlu diadakan hari bahasa untuk hari-hari tertentu.

\section{Rekomendasi Keberlanjutan Program}

Berdasarkan pemaparan-pemaparan mengenai IHT SD Muhammadiyah (Plus) Salatiga dari segi dimensi instructional, institutional, dan behavior maka dapat disimpulkan bahwa program IHT tersebut memiliki pengaruh yang baik untuk meningkatkan kompetensi guru. Oleh karena 
Evaluasi Program Pelatihan In House Training (IHT) Di Sekolah Dasar Swasta | Aih E. Ayuningtyas, dkk.

itu, program tahunan SD Muhammadiyah (Plus) Salatiga ini perlu dilanjutkan dengan beberapa perbaikan. Perbaikan tersebut antara lain: (1) panitia perlu menyusun perencanaan tentang penggunaan metode yang lebih sesuai dengan materi dan tujuan yang hendak dicapai, khususnya pada materi yang memerlukan praktek secara langsung atau simulasi; (2) panitia perlu melakukan analisis kebutuhan guru secara lebih detail, sebagai contoh kebutuhan guru untuk mendapat motivasi dari seorang motivator; dan (3) pihak sekolah perlu memberikan perhatian kepada guru yang ingin mengembangkan prestasinya dengan memberikan pengarahan-pengarahan, atau pun kegiatan-kegiatan yang dapat menunjang potensi guru untuk berprestasi.

\section{DAFTAR PUSTAKA}

Astuti, S., Slameto, S., \& Dwikurnaningsih, Y. (2017). Peningkatan Kemampuan Guru Sekolah Dasar Dalam Penyusunan Instrumen Ranah Sikap Melalui In House Training. Kelola: Jurnal Manajemen Pendidikan, 4 (1), 37-47.

Basri, Hasan dan Rusdiana, A. 2015. Manajemen Pendidikan dan Pelatihan. Bandung: Pustaka Setia

Eliyanto dan Udik Budi Wibowo. 2016. Pengaruh Jenjang Pendidikan, Pelatihan, dan Pengalaman Mengajar Terhadap Profesionalisme Guru SMA Muhammadiyah di Kabupaten Kebumen. Jurnal Akuntabilitas Manajemen Pendidikan. 1 (1), 34-47.

Hammond, Robert L. 1968. Evaluation at The Local Level. Tucson: Project EPIC

Musfah, Jejen. 2011. Peningkatan Kompetensi Guru, Melalui Pelatihan dan Sumber Belajar Teori dan Praktik. Jakarta: Kencana

Pahlevi, Reza. 2016. Evaluasi Program Diklat Kompetensi Guru Sekolah Menengah Kejuruan (SMK) di Balai Pengembangan Pendidikan Kejuruan Provinsi Jawa Tengah. Tesis: Magister Manajemen Pendidikan, Universitas Kristen Satya Wacana
Putri, Ratu Ilma Indra. 2013. Evaluasi Program Pelatihan Pendidikan Matematika Realistik Indonesia (PMRI) Bagi Guru Matematika Sumatera Selatan. Prosiding Seminar Nasional Evaluasi Pendidikan, 1 (1), 522-527.

Rivai, Veithzal dan Murni, Sylviana. 2012. Education Management: Analisis Teori dan Praktik. Jakarta: PT Rajagrafindo Persada

Riza, Eva. 2014. Efektivitas Diklat Berjenjang tingkat Dasar Pendidik Dan Tenaga Kependidikan PAUD. Jurnal Pendidikan Usia Dini 8 (1), 90-100.

Sudana, I Made. Analisis Meta Pada Manajemen Pasca Pelatihan Untuk Meningkatkan Produktivitas Guru di SMK. Jurnal Pendidikan Vokasi. 1 (1),133-156.

Sudjoko, Alfaris. 2012. Peningkatan Kemampuan Guru Mata Pelajaran Melalui In-House Training. Jurnal Pendidikan Penabur, 18 (11), 36-55.

Uysal, Hacer H. 2012. Evaluation of an Inservice Training Program for Primaryschool Language Teachers in Turkey. Australian Journal of Teacher Education. 37 (7), 14-29.

Yusoff, Mohd Azmi Mat, dkk. 2016. Evaluation of School Based Assessment Teacher Training Programme. Creative Education. 2016 (7), 627-638. 